\title{
Applied Research on the Teaching Model of Flipped Classroom in Translation Course for English Majors
}

\author{
Li Huang \\ Huanghe Science and Technology College \\ Zhengzhou, Henan, China, 450063 \\ e-mail: pearhuangli@163.com
}

\begin{abstract}
There exists the phenomenon in translation course for English majors: such as, a large number of students, students' uneven basic level. The traditional teaching model "Teacher centered, students supplement" has been unable to adapt to the needs of students and can not solve the problems in the course. The rise and appearance of flipped classroom changes the traditional teaching mode. This paper is mainly to apply flipped classroom model to translation teaching, combining them to study.
\end{abstract}

Keywords-Flipped Classroom; Teaching mode; Translation course; applied research

\section{INTRODUCTION}

With the integration of IT and translation courses, internet, cloud platform, open class, micro lessons are emerging, which also promotes the teaching reform of translation course. In 2001, the Massachusetts Institute of Technology started "open courseware", and the famous micro class, open class, Salman Khan, founder of the Khan Academy were so popular around the world. [1] More teachers are familiar to flipped classroom gradually in 2011 , causing widespread concern in the education sector. Currently, there are many schools in the United States with a flipped classroom teaching mode, and achieved good teaching effect. But in the domestic, it is rare to apply this advanced teaching concepts and teaching mode, so I combine flipped classroom model with college English professional translation course to empirical research.

\section{A FlipPed Classroom Teaching Mode}

\section{A. The definition of flipped classroom}

Flipped classroom is translated from the English "Flipped Classroom", also known as "reverse the classroom." [2] flipped classroom model subverts the traditional teaching mode, changing the status quo of classroom "teacher-based, student supplement". Flipped classroom model emphasizes providing instructional videos in the network environment and students in class or at home watched video online learning, after finishing watching, teacher conducts discussing and exchanging their own experiences, insights, and the exercises done in the classroom with a student, thus completing the internalization of knowledge. This new teaching model is completely reversed the traditional "teacher explain in class, student do homework after class"

Partial research result of soft science project in Henan province, The code of the project: 132400411199 teaching mode, received good teaching effect, currently, which is very popular in foreign countries.

\section{B. The advantages of turning the classroom}

Traditional teaching model is based on teacher's lecture, ignoring the development of the individual differences of students and student initiative and creativity capabilities. The Flip is a student-centered classroom, emphasizing the personality development of students, independent learning ability of students. Students in class or at home can have a selective reading materials, to arrange time to learn, which makes the students in terms of time and space have great autonomy, and even moving to learn anytime, anywhere. Learning through the network platform, students not only equip with the knowledge but also are improved in ability, such as, language skills, cooperation, innovation has been developed.

\section{STUDENTS CHARACTERISTICS OF COLLEGE ENGLISH MAJORS TRANSLATION COURSE}

\section{A. Students uneven level of English translation}

Students from high school into the university has a certain level of English, but a large gap between the level of students translation, some students even has a problem in basic sentence translation, but some students are well done in translating passages, which reflects the student different basic level.

\section{B. Students have different learning interest}

Students have great interest in learning English translation. For the translation knowledge, they can understand thoroughly and sentence translation is ideal. And some students only interested in professional courses, little interest in English classes, truancy, or even take the test.

\section{SOME OF THE PROBLEMS EXISTING IN TRANSLATION COURSES}

\section{A. Curriculum}

Currently, translation course is generally for junior college students to study. Some schools offer a semester, and some open two-semester course, last semester is English to Chinese Translation, Chinese to English is next semester. In general, translation course should enable students to learn a bit longer, because of the relatively strong practical course, 
students should be more practical to improve translation capabilities.

\section{B. lectures}

Due to the strong practical translation course, there are more translation books in bookstore. This makes the school in the choice of materials to be carefully, chosing the books according to their own school characteristics and students level. In classroom, students should learn more about translation knowledge, and combine the theory with practice together.

\section{The teaching methods}

Translation course is a practical course, it requires teachers to impart more knowledge to students. The traditional chalk and blackboard teaching model can not meet the needs of students, and therefore it must be reformed. Through the use of multimedia network information technology, students can obtain more knowledge and they will be more focused on in class, thus achieving the expected results of the course.

\section{FOURTH, THE APPLICATION OF FLIPPED CLASSROOM IN ENGLISH PROFESSIONAL TRANSLATION COURSE}

Famous American professor Robert Talbert repeatedly use flipped classroom model in the teaching process, which summed up a structural model about flipping the classroom teaching mode. [3] He divided flipped classroom model into three parts, namely, before class, in class and after school. Before class, students mainly watch the video, students complete the job and summarize the contents what they see and publish insights in class, students mainly summarize evaluation and feedback after school.

\section{A. Before class}

\section{1) Teachers in producing video}

Teacher should do the video to provide material before class. General, video can be collected through two channels, online resource materials available, this is generally not suitable. Teachers should make instructional videos from the schools according to their nature and characteristics of the students and the teaching objectives and requirements of the course. The time of video is not suitable for too long, usually 10 minutes or so, it is easy to focus students' attention, triggering students active learning and thinking. The author usually select the material according to the characteristics of the schools at the time of making the translation video. The author is in a three institutions, students are relatively poor in basis. Although the name of translation course called "translation theory and practice," for junior students, students are not interested in translation theory. Just mention translation theory that the more abstract and esoteric knowledge, the students wanted to nap. Teachers should select a number of practical novelty themes for students to do translation practice according to the characteristics of students, so as to improve the students' enthusiasm, initiative and practical translation capabilities.

\section{2) Students watch the video}

Students watch video freeing from the time and place restrictions, students can watch videos at home, you can see during the day or the night. Looking tired, you can take a break and then continue watching. Students can take notes what they do not understand while watching the video and they can discuss and exchange with students in the classroom. About the author's translation course, I ask students to watch videos in the dormitory at night or during the day there is no class, they can watch the video translation. During the process of watching video, students should take notes and write down what they do not understand or the difficult knowledge, and then get on discussing in the classroom. Each student must be required to identify difficulty and focus about learning video materials, which would enable students to be more careful study hard.

\section{3) Pre-class exercises and student exchange}

After watching the video, the students should complete assignments ahead of time. For example, students can exchange difficult problems encountered during the process of doing homework with fellow classmates or teachers through social media (ie, chat rooms or message boards). They can exchange the difficult problems with the teachers, thereby increasing students interest in learning. In the author's translation course, generally, after watching the video, the teacher will give the students translation work or exercise related to the chapter or section. The main purpose is to allow students to consolidate the knowledge what they have learned in this chapter, you can discuss what you are not sure or don't understand with teachers and students through the BBS, QQ, Wechat, Microblog. So students can actively participate in and build on the knowledge and they can better grasp and understand what they have learned about the knowledge in translation.

\section{B. In class}

Classroom activities during design, based on constructivist learning theory, they can give full play to the enthusiasm of the students, in order to achieve internalization of knowledge.

\section{1) Determine the problem}

In flip classroom activities, teachers can do the difficult problems what they encountered during watching the video before and after class and even to discuss with the students through remote yet to be resolved, and which can be raised in the classroom to discuss further with teachers and students together. On the other hand, the teacher can put forward the difficult problem for discussion. In the author's translation class, started using the new teaching mode-flip the classroom, the students do not seem to be adapt to this new teaching model, still immersed in the traditional teaching model, proactive questions, identify problems students are comparatively less. After a few weeks, adapting to this model, the initiative, enthusiasm of students in the classroom is very high, more and more issues are raised, and each student has a question, therefore, entire classroom is very positive dynamic, the atmosphere is very good, which has also been endorsed and praised by the school supervisors.

2) To solve the problem 
For translation issues raised in the flipped classroom, students are free to choose their own interest or a better understanding to the issues or topics to independently explore and develop students' sense of independence and ability to learn. That reverse flip classroom, that is, students accept knowledge and questions from the traditional passive acceptance to actively independent thinking and solving problem, so that students in independent study reached the building to the internalization of knowledge and knowledge systems. In the author's translation lesson, each student is determined by raising the question, and then discuss the problems between teachers and students in the classroom, the students' difficult problems are finally solved, which students had to re-build on the knowledge, cultivating and lifting students independent learning ability.

\section{3) Exploration activities}

About the translation exploration activities, the students were divided into several groups, each 2-5 people, and each group identify a leader, making inquiry for discussion of the issues raised in each group. Through group discussions and exchanges to complete learning tasks, teachers should pay attention to the students to explore the dynamic and timely guidance. In the author's translation classroom, because each class is the standard class 30, each group of five people, divided into six groups. Each group try to make men and women with complementary advantages and disadvantages in each group, and which has at least a better English students. In exploring the process of translation problems, each of which students are actively involved in the discussion and inquiry, students will find and raise new questions in the process of discussion, then I will be ready to give students guidance and answers. Such students dialectical thinking, logical thinking and research capacity has been correspondingly increased.

\section{4) Exchange the results}

For the questions put forward jointly, students display and exchange the outcome through independent thinking and collective inquiry, the results of the final panel discussion through various forms (achievements presentations, small game, debate or report) will implement, and thus learn to share harvest. In the author's translation course, generally, the author takes the form of presentation or debates the outcome to demonstrate and communicate the results, students can share and learn from each other by showing and debating, to share in learning, so that students' learning motivation and translation capabilities will be continuously improved.

\section{5) Evaluation and feedback}

Feedback and Evaluation in flipped classroom is very different from the traditional classroom. In traditional classroom, teacher is generally given to the evaluation, and in a new classroom, addition to the teachers, experts, scholars, students can participate, which reflects the multi-dimensional classroom about the feedback of the new evaluation system. [4] As well as multi-mode: You can be a quantitative evaluation and qualitative evaluation; individual evaluation and team evaluation; formative assessment and summative evaluation; process evaluation and outcome evaluation; self-evaluation and evaluation of others. Through multi-dimensional and multi-mode feedback, teacher finally determins to the next teaching plan of the lesson. In the author's translation course, through student exchanges and showcase achievements, the author himself, translation experts or college professor Qi will visit the site and even make review, combining individual evaluation with team evaluation, process evaluation and outcome evaluation, resulting to achieve a multi-dimensional, multi-mode evaluation system in translation classroom.

\section{After-school}

Professors in Franklin Institute and Zhang Jinlei think flipped classroom model is mainly composed of two parts: pre-class and upper class, but the summary and reflection after school is also very important. [5] Teachers and students are required to summarize and reflect the problem in the classroom and then spread to the network platform for mutual discussion between students and teachers. After finishing, these materials can also be saved for the long run, in order to prepare to consult. The students who did not participate in class discussions can also be remedial learning after-school. Therefore, before class, in class, after school, the three parts are complementary and mutually integrated.

\section{CONCLUSION}

Flipped classroom model is applied to the teaching of English professional translation, which is a useful attempt and active exploration. It has changed the traditional way of teaching in translation course and the role between teachers and students. In order to play the students' enthusiasm, initiative, creativity and independence, students' ability to learn independently is cultivated. Simultaneously, the quality and effectiveness of teaching are progressed and students practical translation capability has also been greatly improved to meet the demand for qualified personnel.

\section{REFERENCES}

[1] Zhang Yueguo, Zhang Yujiang. Perspective "flipped classroom" [J] primary and secondary IT education, 2012 (3): 3-5.

[2] Jinling. "Flipped classroom" flip what? [J] Chinese IT education, 2012 (9): 18-20.

[3] Zhang Jinlei, Wang Ying, Lobe. Flipped classroom model study [J] Journal of Distance Education, 2012 (4): 46-51.

[4] Wu Jinjin. Vocational flipped classroom teaching mode [J]. China Educational Technology Equipment, 2013 (8): 86-87.

[5] Liu Guihua. Application of flipped classroom in college courses of Computer Culture Foundation [J] . 2013 (5): 174-176. 